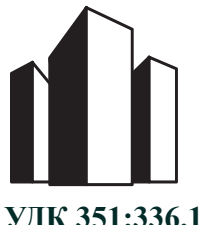

doi: $10.15421 / 15201716$

\section{Роль бюджетно-податкової сфери у підвищенні фіскальної безпеки держави}

\author{
Г.В. Бритова, Є.В. Скрильник \\ Класичний приватний університет, \\ Запоріжжя, Україна
}

У статті проаналізовано стан фіскальної системи України, розглянуто дисбаланси бюджетно-податкової сфери та охарактеризовано їх тенденції. Обгрунтована потреба забезпечення фіскальної безпеки та розробки відповідних механізмів протидії фіскальним ризикам та загрозам, що здатні забезпечити стабілізацію бюджетно-податкової сфери та реалізацію функцій бюджету. Надані практичні рекомендації щодо налагоджування та вдосконалення функціонування означених бюджетно-податкових напрямів розвитку для стабілізації існуючих позитивних змін у сфері фіскальної безпеки країни. Встановлено, що своєчасний моніторинг рівня фіскальної безпеки держави дозволяє відстежити можливі негативні фінансові явища та потенційні загрози, які сприяють посиленню депресивних економічних тенденцій, виявити джерела витоку існуючих загроз з метою оперативного та своєчасного реагування на них, реалізувати необхідні заходи щодо покращення функціонування фіскального сектора, що позитивно впливатиме на розвиток фінансової системи держави загалом. Виявлено, що перспективним $є$ реалізація нових інноваційних проектів, які будуть спрямовані на зміцнення фіскальної безпеки держави.

Ключові слова: Державний бюджет; національна безпека держави; бюджетно-податкова сфера; фіскальна безпека держави; соціально-економічний розвиток

\title{
Role of fiscal and budgetary sphere in the strengthening of the fiscal security of the state
}

\author{
H.V. Brytova, Y.V. Skrylnyk \\ Classic private university, Zaporizhzhia, Ukraine
}

The purpose of the article is to analyze the fiscal system and to justify the recommendations on strategic directions of the state fiscal security's guarantee in the context of adherence to national interests of Ukraine. General and specific scientific, economic and mathematical methods have been used in the article, for example methods of dialectical and scientific knowledge. Measurement, comparative characteristics have been used to identify the problems of the fiscal sector and to specify the possible directions of fiscal security's improvement. In the article the state fiscal system in Ukraine has been analyzed by the author, fiscal sector imbalances have been studied and their trends have been described. It has been found that the level of the state fiscal security depends on positive and negative factors, which are formed under certain conditions and situations and exist both on global and local levels. It has been argued by the author that comprehensive study of fiscal state security factors allow us finding potential dangers and threats and also it allows reducing possible damage in the process of implementation of necessary management actions. Also the need to ensure fiscal security and to develop appropriate mechanisms to counteract fiscal risks and threats, which can stabilize the fiscal sector and help to improve budget functions, has been substantiated by the author. Practical recommendations on the establishment and improvement of the functioning of the above mentioned fiscal and tax areas of development have been provided by the author of the article in order to stabilize the existing positive changes in state's fiscal security sphere. It has been found that prompt monitoring of state fiscal

Цитування даної статті: Бритова Г.В. Роль бюджетно-податкової сфери у підвищенні фіскальної безпеки держави / Г.В. Бритова, С.В. Скрильник // Аспекти публічного управління. - 2017. - Т. 5. - № 5-6(43-44). C. $44-51$.

Citation of this article: Brytova, H.V., Skrylnyk, Y.V., 2017. Rol' byudzhetno-podatkovoyi sfery u pidvyshchenni fiskal'noyi bezpeky derzhavy [Role of fiscal and budgetary sphere in the strengthening of the fiscal security of the state]. Public administration aspects 5, 5-6(43-44), 44-51. doi: 10.15421/15201716 (in Ukrainian).

Peer-reviewed, approved and placed: 20.04 .17 
security helps to predict possible negative financial hazards and potential risks that contribute to the strengthening of depressive economic trends. This helps to identify sources of the leakage of current threats for prompt and timely response, to implement necessary actions in order to improve the functioning of the fiscal sector and to impact positively on the development of state's financial system in general.

The research made it possible to systematize the existing fiscal problems which contribute to the decrease of the fiscal security of Ukraine. It has been proved that strengthening of the state fiscal security is possible by conducting a balanced policy on creation of a favorable fiscal space and effective strategic management of fiscal security. It has been defined by the author that the implementation of new innovative projects, which would help to strengthen the state's fiscal security, is prospective.

Keywords: State budget; national security; fiscal and budgetary sphere; fiscal security; social and economic development

\title{
Роль бюджетно-налоговой сферы в повышении фискальной безопасности государства
}

\author{
А.В. Бритова, Е.В. Скрильник \\ Классический приватный университет, Запорожье, Украина
}

В статье проанализировано состояние фискальной системы Украины, рассмотрены дисбалансы бюджетно-налоговой сферы и охарактеризованы их тенденции. Обоснована необходимость обеспечения фискальной безопасности и разработки соответствующих механизмов противодействия фискальным рискам и угрозам, которые способны обеспечить стабилизацию бюджетно-налоговой сферы и реализации функций бюджета. Даны практические рекомендации относительно налаживания и усовершенствования функционирования указанных бюджетно-налоговых направлений развития для стабилизации существующих позитивных изменений в сфере фискальной безопасности страны. Установлено, что своевременный мониторинг уровня фискальной безопасности государства позволяет отследить возможные негативные финансовые явления и потенциальные угрозы, которые способствуют усилению депрессивных экономических тенденций, выявить источники утечки существующих угроз с целью оперативного и своевременного реагирования на них, реализовать необходимые меры по улучшению функционирования фискального сектора, положительно влиять на развитие финансовой системы государства в целом. Выявлено, что перспективным является реализация новых инновационных проектов, которые будут направлены на укрепление фискальной безопасности государства.

Ключевые слова: Государственный бюджет; национальная безопасность государства; бюджетно-налоговая сфера; фискальная безопасность государства; социально-экономическое развитие

Постановка проблеми. Модернізація та стабілізація, насамперед, внутрішньоекономічних процесів $є$ визначальним фактором підтвердження суб'єктності держави та їі стійкості: політичної, економічної, військової, інформаційної. Важливою передумовою модернізації $\epsilon$ ефективна фінансова та, зокрема, бюджетно-податкова система. Стан захищеності фіскальних інтересів держави, підприємств та громадян, здатність бюджетно-податкової системи своєчасно виконувати функції, адекватно реагувати на виклики, протидіяти ризикам і загрозам зовнішнього та внутрішнього характеру визначається як фіскальна безпека держави. В свою чергу, належне фінансове забезпечення є невід'ємним елементом військової, політичної та інформаційної, а зрештою національної безпеки держави.

Виклики та ризики, зокрема фінансовоекономічні, що виникають на сучасному ета- пі та обумовлюють подальші трансформаційні процеси, стають вагомим фактором, який впливає на траєкторію розвитку держави. Втрати доходів бюджету, зростання видаткових зобов'язань, збільшення дефіциту бюджету, зростання державного боргу спричиняють виникнення бюджетних ризиків та актуалізують питання фінансової безпеки бюджетів.

Саме врегулювання фіскальної безпеки дає змогу мінімізувати бюджетні ризики, стабілізувати фінансові потоки, а також забезпечити наповнення бюджету та його розподіл на розв'язання нагальних проблем. Отже, зростає потреба забезпечення фіскальної безпеки та розробки відповідних механізмів протидії фіскальним ризикам та загрозам, що здатні забезпечити стабілізацію бюджетно-податкової сфери та реалізацію функцій бюджету.

Аналіз досліджень та публікацій. Дослідження проблематики забезпечення 
фіскальної безпеки держави засноване на наукових працях вітчизняних (3. Варналій, О. Власюк, Я. Жаліло, М. Срмошенко, Ю. Іванов, О. Ляшенко, В. Мельник, А. Мокій, В. Мунтіян, Н. Нижник, А. Соколовська, А. Сухоруков, Г. Ситник, С. Юрій) і зарубіжних вчених (Ш. Бланкарт, I. Джубек, Д. Олвей, Дж. Стігліц, В. Фехлер) у сфері функціонування національної безпеки та іiі структурних елементів.

Метою дослідження $є$ аналіз стану фіскальної системи та обгрунтування рекомендацій щодо стратегічних напрямів забезпечення фіскальної безпеки держави у контексті слідування національним інтересам України.

Виклад основного матеріалу. На початку 2014 р. в Україні зберігалася нереформована фінансова система, яка на тлі неефективної ренто-орієнтованої моделі розвитку вітчизняної економіки була дуже вразливою до будьяких зовнішніх впливів [8]. У бюджетно-податковій сфері накопичилися дисбаланси, які характеризувалися наступними тенденціями.

Зростання бюджетних та квазібюджетних дефіцитів при невиконанні прогнозних макропоказників економічного та соціального розвитку, збереження високої частки видатків на фінансування соціально-культурної сфери, зростання видатків на пенсійне забезпечення, низького рівня капітальних видатків. Середньомісячний вхідний залишок коштів на ЄКР [1] зменшувався із 7,9 млрд грн у 2011 р. до 4,9 млрд грн у 2012 р. та 3,0 млрд грн у 2013 р. На початку листопада 2014 р. він був найменшим за останні 10 років - склав лише 0,4 млрд грн. Недонадходження податків компенсувалося щороку рекордно зростаючими перерахуваннями коштів НБУ до бюджету 3 11,9 млрд грн у 2011 р. до 23,6 млрд грн у 2013 р. та 28,3 млрд грн у 2014 р.

Високий рівень податкового навантаження зумовлював тінізацію заробітних плат (близько $41 \%$ на фонд оплати праці, у т.ч.: $37 \%$ нарахування ССВ $+3,6 \%$ утримання $\mathrm{CCB}+15 / 17(20) \%$ ПДФО). Відповідний показник був одним із найвищих серед країнчленів ОЕСР. А загалом частка перерозподілу ВВП через видатки сектору загального державного управління в Україні сягнула рекордних 49,0\% ВВП в 2012 р. та 48,1 \% ВВП в 2013 р., ставши найбільшою серед країн, подібних за рівнем економічного розвитку.

Неправомірні дії податкових органів та зростання переплат податків і зборів до бюджету сумлінних платників податків органи Міністерства доходів і зборів України неформально змушували здійснювати переплати податків в рахунок майбутніх податкових періодів. Фактичні переплати до Зведеного бюджету України збільшувалися 3 45,0 млрд грн станом на 01.01.2010 р. до 62,5 млрд грн станом на 01.01.2014 р. (з урахуванням авансових внесків 3 податку на прибуток підприємств).

Збільшення «прихованого» дефіциту бюджету. Разом із збільшенням вартості ціни імпортованого $з$ РФ природного газу збільшувався й дефіцит НАК «Нафтогаз», навіть 3 урахуванням Харківських угод. Україна в 2013 р. мала найвищий обсяг споживання природного газу (50,4 млрд куб. м) серед країн-сусідів Східної Свропи - Угорщини $(6,9)$, Польщі $(14,1)$ та Словаччини $(4,2)$.

Розширення кола податкових пільг, мінімізація оподаткування та фіктивне відшкодування ПДВ дозволялися наближеним до корумпованої влади платникам податків. Формальне зменшення заборгованості за відшкодуванням ПДВ з 24,2 млрд грн на 10.01.2010 p. до 14,9 млрд грн компенсувалося випуском ОВДП. Станом на 20.03.2014 p. iї залишок зріс до 21,6 млрд грн.

Недонадходження податків компенсувалося щороку рекордно зростаючими перерахуваннями коштів НБУ до бюджету - 3 11,9 млрд грн у 2011 р. до 23,6 млрд грн у 2013 р. та 28,3 млрд грн у 2014 p.

Збільшувався обсяг видатків державної підтримки вугледобувних підприємств 3 5,8 млрд грн у 2010 р. до 13,3 млрд грн у 2013 p. Причому собівартість видобутку 1 тонни вугілля на недержавних шахтах становила від 300 грн (рентабельність 70 \%), а на шахтах державної форми власності - 600-1300 грн.

Зростання соціальних стандартів на тлі відсутності економічного зростання та нереформованості гуманітарної сфери було штучним. 3 метою купівлі лояльності громадян створювалася імітація поліпшення добробуту за рахунок коштів бюджету. Питома вага захищених статей у загальному фонді Зведеного бюджету становила 89,8 \% у 2013 р. проти $82,2 \%$ у 2011 p.

Щороку посилювалася залежність збалансованості Пенсійного фонду та місцевих бюджетів від трансфертів 3 державного 
бюджету. До кінця 2013 р. ресурси для підтримки видимості «успішності» були вичерпані. Дефіцит державного бюджету зріс $3-1,8$ $\%$ ВВП у 2011 р., до -3,8 \% ВВП у 2012 р. та $-4,4 \%$ у 2013 р. Таким чином, під тиском загострення бюджетних дисбалансів та низки зовнішніх факторів держава стала вимушено «жити у борг», та майже втратила економічну і політичну незалежність.

Державний бюджет щорічно компенсував зростання квазіфіскальних дефіцитів, а додаткове навантаження посилило зростання державного боргу. Внаслідок дотаційності газових тарифів від їх ринкового рівня щорічно виникав величезний дефіцит найбільшого в Україні газового монополіста. Законами про державний бюджет на відповідні роки надавалося право Кабінету Міністрів України здійснювати випуск облігацій внутрішньої державної позики (ОВДП) з подальшим придбанням у державну власність в обмін на зазначені облігації акцій додаткової емісії Публічного акціонерного товариства «Національна акціонерна компанія «Нафтогаз України». Кошти у подальшому спрямовувалися на закупівлю нових обсягів природного газу.

У 2013 р. надходження внутрішніх запозичень дорівнювали 109,0 млрд грн, 3 яких 8,0 млрд грн становили надходження від випуску ОВДП для капіталізації НАК «Нафтогаз України». В 2014 р. відповідні показники сягнули рекордних значень - 227,6 млрд грн, 3 яких 96,6 млрд грн ОВДП для газового монополіста. Реформа енергетичного сектора із поступовим наближенням дотаційних тарифів на природний газ до економічно обгрунтованого рівня дозволила скоротити в 2015 р. фінансову допомогу НАК «Нафтогазу» до 29,7 млрд грн із загального обсягу 99,0 млрд грн держаних внутрішніх запозичень. Таким чином, упродовж п'яти років на безпосереднє фінансування НАК «Нафтогаз» через штучно дешевий для споживачів природний газ було спрямовано понад 165 млрд грн ОВДП терміном випуску від 3 до 7 років.

Напередодні переходу збройної агресії на сході країни в активну воєнну фазу Україна мала із північним сусідом тісні економічні зв'язки, передусім в енергетичній, торговельній та транспортній сферах. Розрив таких зв'язків негативним чином позначився на фіскальній безпеці. Однак він не мав альтернативи у політичному та соціальному аспекті, а найголовніше - 3 точки зору відсутності економічних перспектив України у разі вступу до Митного союзу [8].

Поряд із викликами, ризиками та загрозами фіскальній безпеці Україна вже досягла ряд вагомих перемог у бюджетно-податковій сфері, зокрема:

1. Зниження податкового навантаження на економіку. Рівень перерозподілу ВВП у доходи сектора загального державного управління знижено із зменшенням податкового навантаження на фонд оплати праці. Рівень перерозподілу склав рекордних у 2012 р. 44,7 \% ВВП та в 2013 р. 43,3 \% ВВП, залишаючись головним фактором тінізації значної частки національної економіки. В 2015 р. на першому етапі разом із запровадженням понижуючого коефіцієнта для ставки ССВ було знижено частку перерозподілу до 42,1 \% ВВП, а в 2016 р. разом із остаточним зниженням ставки ССВ вдвічі вона знаходилася на рівні $38,1 \%$ ВВП.

Зниження податкового навантаження на бізнес дозволило надати більше приватного інвестиційного ресурсу в економіку для іiі структурної перебудови та модернізації. Водночас таке зниження має об'єктивні обмеження - високу частку видатків бюджету на оборону та соціальне спрямування.

Проблемні аспекти: за підсумками 2016 р. надходження єдиного внеску становили 95,5 мдрд грн, що на 37,5 млрд грн, або на 28,4\% менше відповідного показника минулого 2015 p. (132,0 млрд грн). Відтак з метою детінізації заробітних плат та зменшення дефіциту бюджету Пенсійного фонду України Урядом в другій редакції проекту Закону України «Про Державний бюджет України на 2017 рік» [4] було прийнято рішення про збільшення мінімальної заробітної плати вдвічі з 1600 до 3200 грн. Економісти висувають різні сценарії поведінки роботодавців залежно від галузей та регіонів на такі дії - від легалізації заробітних плат до переведення працівників на неповний робочий день / скорочення малокваліфікованих робітників / зростання офіційного безробіття та неформальної зайнятості. Однозначно слід очікувати, що відповідне збільшення показника МЗП позначиться зростанням собівартості продукції (товарів, робіт, послуг), а отже - на показнику споживчої інфляції в 2017 р.

2. Започаткування, врегулювання та 
поступова успішна реалізація процесу децентралізації влади, зокрема бюджетна децентралізація 3 метою підвищення фінансової спроможності новостворених добровільно об'єднаних територіальних громад (ОТГ).

У 2015 р. 794 сільські, селищні та міські ради, до складу яких входять 2015 населених пунктів, провели перші місцеві вибори 25 жовтня та добровільно об'єдналися у 159 територіальних громад. 32016 р. вони перейшли на прямі міжбюджетні відносини 3 державним бюджетом.

32016 року надходження власних ресурсів до загального фонду місцевих бюджетів зросли в 1,4 раза, або на 34,2 млрд грн порівняно 3 минулим роком та склали 103,9 млрд грн. Зокрема надходження доходів загального фонду місцевих бюджетів 159 ОТГ (з урахуванням трансфертів 3 державного бюджету) склали майже 4,98 млрд грн, що більше ніж у 6 разів порівняно 3 надходженнями 2015 року до бюджетів місцевих рад, які увійшли до складу ОТГ. Завдяки змінам до податкового та бюджетного законодавства у контексті децентралізації надходження власних доходів місцевих бюджетів об'єднаних громад зросли більше ніж у 3 рази (на 1,5 млрд грн) порівняно з 2015 роком (з 0,7 млрд грн до 2,2 млрд грн). Об'єднання громад дозволило збільшити власні доходи бюджетів ОТГ на 1 жителя відповідної території. В середньому показник (у порівнянні з 2015 роком) по всіх ОТГ збільшився на 1100 грн. (з 518 грн до 1620 грн).

3. Вжито заходів із фіскального регулювання суб'єктів господарювання, що здійснюють свою діяльність у зоні АТО. Проведення АТО в окремих регіонах України фактично унеможливлює будь-яку діяльність фізичних осіб та суб'єктів господарювання у цій зоні, а також виконання функцій органами влади, в тому числі податкових та митних, які мають забезпечувати облік платників податків, контроль за їх справлянням. Запровадження 31 липня 2015 р. у повноцінному режимі системи електронного адміністрування ПДВ унеможливило створення фіктивного податкового кредиту i, як наслідок, зменшення податкових зобов'язань та отримання незаконного бюджетного відшкодування підприємствами 3 тимчасово окупованих територій.

Проблемні аспекти: невиконання ДФСУ у повній мірі вимог щодо інформації, яка має публікуватись у складі щоденних Реєстрів заяв про бюджетне відшкодування ПДВ. Відповідне порушення призводить до непрозорості процесу бюджетного відшкодування та, відповідно, створює корупційні ризики з боку податкових органів. Міністерство фінансів України також фіксує випадки систематичного втручання з боку посадових осіб ДФСУ у діяльність СЕА ПДВ, порушення хронологічного порядку та незаконного відшкодування ПДВ. Відтак необхідне оприлюднення всіх відомостей щодо бюджетного відшкодування на відомчому сайті ДФСУ.

Доступ до важливих агрегованих показників щодо сум переплат усіх податків, сум донарахувань за актами перевірок, кількості проведених планових/позапланових перевірок, сум невідшкодованого ПДВ є закритим, дані фрагментовані та неповні. Закритість даних дозволяе контролюючим органам маніпулювати ними, зловживати своїми правами, не виконувати/неналежно виконувати свої обов'язки, що створює корупційні ризики. Відтак необхідне створення моніторингової системи агрегованих показників для громадської оцінки та контролю діяльності ДФСУ [5].

4. Запроваджено верифікацію отримувачів усіх видів соціальних виплат. Регулярно виявляються випадки незаконного отримання відповідних видів допомоги. Відтак гостро постала необхідність здійснення процесу верифікації отримувачів соціальних виплат та пенсій. 3 цією метою в грудні 2015 р. за ініціативи Мінфіну Верховна Рада ухвалила зміни до законодавства, що створюють підгрунтя для іï проведення. Окрім того, 11 та 18 лютого 2016 р. Кабінет Міністрів затвердив 7 Постанов, що дозволили завершити створення нормативної бази для функціонування процесу верифікації. Він відбувається в межах структурного підрозділу Управління верифікації та моніторингу виплат Міністерства фінансів.

В Україні на рік виплачуються значні обсяги соціальних виплат населенню. В 2015 р. вони фінансувалися державою на рівні 364,0 млрд грн або 18,4 \% ВВП, а тому числі пенсії (265,8 млрд грн або 13,4 \% ВВП), бюджетні соціальні програми, виплати по безробіттю та втрати працездатності. Частка соціальних видатків у загальній структурі видатків сектора загального державного управління знижувалася 347,6 \% у 2013 р. [9] до 45,6 \% у 2014 
p. та 42,5 \% у 2015 р. Завдяки запровадженню верифікації питома вага соціальних видатків держави очікується на рівні 378,5 млрд грн або 16,6 \% ВВП (39,7 \% видатків держави) [10].

Таким чином, означене підштовхнуло до вирішення однієї із загроз державної бюджетної та соціальної політик - фіктивних отримувачів соціальних виплат, а отже має посилити національну економічну безпеку.

5. Запроваджено систему електронних публічних закупівель «Prozorro», яка надала змогу здешевити вартість та прискорити постачання матеріально-технічного забезпечення для Збройних сил України. Міністерство оборони України одним із перших розпочало проведення публічних закупівель через електронну систему «ProZorro» ще на етапі пілотного проекту з 29 червня 2015 р. Станом на 14.11.2016 р. воно провело 1,69 тис. закупівель (в т.ч. власне міністерство - 1,3 тис., ДП «Укроборонпром» - 0,2 тис., а також військові частини та авіація). За очікуваної вартості 12,48 млрд грн економія склала 0,64 млрд грн. Кількість учасників становила 988, а пропозицій на торги в середньому надійшло $3,47[3]$.

6. Забезпечення прозорості використання публічних коштів через портал «Е-дата» в рамках проекту «Прозорий бюджет». Стратегією сталого розвитку «Україна-2020» [6], пріоритетом в управлінні публічними фінансами визначено підвищення прозорості та ефективності їх розподілу й витрачання. У 2015 р. запроваджені електронна система публічних закупівель «ProZorro» та єдиний веб-портал використання публічних коштів «E-data», який реалізовується як складова проекту «Прозорий бюджет». У липні 2016 p. ïx поєднала пошуково-аналітична система «.007». Для забезпечення прозорості публічних фінансів у майбутньому необхідне подальше наповнення даними службових кабінетів розпорядників та отримувачів бюджетних коштів за рахунок приєднання державних та комунальних підприємств до «Е-дата», розбудова аналітичного блоку пор- талу, наповнення порталу відкритих даних новими наборами даних, налагодження електронного декларування державних службовців. Перспективним $\epsilon$ залучення широких верств громадськості до контролю витрачання публічних коштів. порталу відкритих даних та відкриття доступу до майнових реєстрів.

Важливо налагоджувати та вдосконалювати функціонування означених бюджетно-податкових напрямів розвитку для утвердження існуючих перемог. Перспективним є реалізація нових інноваційних проектів, що будуть спрямовані на зміцнення фіскальної безпеки держави.

Висновки. Забезпечення перемоги у фінансовій сфері переліченими заходами не обмежується, але вони спроможні надати основний позитивний ефект.

Серед інших можливостей $є$ інституційна реформа ДФС, спрощення податкового адміністрування та митних процедур, удосконалення програмно-цільового методу планування видатків бюджетних коштів, посилення взаємодії органів державного фінансового контролю, зокрема через електронний документообіг та ін. Невід'ємною складовою фіскальної безпеки є монетарна компонента - стабільність грошово-кредитної та капіталізація банківської систем. Фіскальна та монетарна політики мають належним чином координуватися в процесі злагодження спадних фаз економічного циклу.

Вдосконаленню інституційного середовища реалізації фіскальної політики держави мають сприяти результативне завершення антикорупційної, правоохоронної та судової реформ із забезпеченням незалежності від волі третіх осіб. Всі разом вони покликані надати синергетичного ефекту. Високий рівень професіоналізму та компетенції виконавців - державної служби на всіх рівнях - має стати запорукою незмінності вектора. На всіх етапах реалізації реформ є важливим прозорий процес перебігу та публічне звітування влади для інституцій громадянського суспільства, зацікавлених сторін та кожного свідомого українця. 
БІБЛІОГРАФІЧНІ ПОСИЛАННЯ:

1.Власюк О.С. Фіскальна безпека України в умовах гібридної війни: виклики, ризики, загрози та напрями реагування / О.С. Власюк та ін. - К.: НІСД, 2016. - 71 с.

2. Вхідне сальдо ЄКР / Державна казначейська служба України. [Електронний ресурс]. - Режим доступу : http:// www.treasury.gov.ua/main/file/link/334916/file/EKR.xls

3. World Economic Outlook Database / International Monetary Fund. - Oct., 2016. [Electronic recourse]. - Access mode: http:/www.imf.org/external/pubs/ft/weo/2016/02/weodata/index.aspx

4. Модуль аналітики системи публічних електронних закупівель ProZorro, Міністерство оборони України [Електронний ресурс]. - Режим доступу: http://bi.prozorro.org/sense/app/fba3f2f2-cf55-40a0-a79f-b74f5ce947c2/sheet/ $\mathrm{HbXjQep/state/analysis}$

5. Проект Закону України «Про Державний бюджет України на 2017 рік» від 15.09.2016 р. №5000 [Електронний pecypc]. - Режим доступу: http://w1.c1.rada.gov.ua/pls/zweb2/webproc4_1?pf3511=60032

6. Розпорядження Кабінету Міністрів України «Деякі питання запобігання корупції в міністерствах, інших центральних органах виконавчої влади» від 05.10.2016 p. №803-p [Електронний ресурс]. - Режим доступу : http:// zakon5.rada.gov.ua/laws/show/803-2016-\%D1\%80

7. Указ Президента України «Про Стратегію сталого розвитку «Україна-2020»» №5/2015 від 12.01.2015 р. [Електронний ресурс]. - Режим доступу: http://zakon3.rada.gov.ua/laws/show/5/2015/

8. Україна офіційно приєдналася до Угоди COT про державні закупівлі (GPA) / Міністерство економічного розвитку і торгівлі України. - [Електронний ресурс]. - Режим доступу : http://www.me.gov.ua/News/Detail?lang=ukUA\&id=5ce283a6-3c61-4fa6-9aed-17d65194daad\&title=UkrainaOfitsiinoPridnalasiaDoUgodiSotProDerzhavniZakupiv li-gpa-

9. Ukraine: Request for Extended Arrangement Under the Extended Fund Facility and Cancellation of Stand-By Arrangement-Staff Report; Press Release; and Statement by the Executive Director for Ukraine / International Monetary Fund. - March 12, 2015. - Country Report No. 15/69. [Electronic recourse]. - Access mode: http://www.imf.org/external/ pubs/cat/longres.aspx?sk=42778.0

10. Ukraine: Second Review Under the Extended Fund Facility and Requests for Waivers of Non-Observance of Performance Criteria, Rephasing of Access and Financing Assurances Review-Press Release; Staff Report; and Statement by the Executive Director for Ukraine / International Monetary Fund. - October 03, 2016. - Country Report No. $16 / 319$. [Electronic recourse]. - Access mode: http://www.imf.org/external/pubs/cat/longres.aspx?sk=44318.0

\section{REFERENCES:}

1. Vlasyuk, O.S., 2016. Fiskal'na bezpeka Ukrayiny v umovakh hibrydnoyi viyny: vyklyky, ryzyky, zahrozy ta napryamy reahuvannya [The fiscal security of Ukraine in a hybrid war: challenges, risks, threats and responses]. K.: NISD, 71 (in Ukrainian).

2. Vkhidne sal'do YeKR [Incoming CRO]. Derzhavna kaznacheys'ka sluzhba Ukrayiny. Access mode: http://www.treasury.gov.ua/main/file/link/334916/file/EKR.xls (in Ukrainian).

3. World Economic Outlook Database / International Monetary Fund. - Oct., 2016. Access mode: http:/www.imf.org/ external/pubs/ft/weo/2016/02/weodata/index.aspx

4. Modul' analityky systemy publichnykh elektronnykh zakupivel' ProZorro, Ministerstvo oborony Ukrayiny [ProZorro Public Procurement System Analytic Module, Ministry of Defense of Ukraine]. Access mode: http://bi.prozorro.org/ sense/app/fba3f2f2-cf55-40a0-a79f-b74f5ce947c2/sheet/HbXjQep/state/analysis (in Ukrainian).

5. Proekt Zakonu Ukrayiny «Pro Derzhavnyy byudzhet Ukrayiny na 2017 rik» vid 15.09.2016 r. № 5000 [Draft Law of Ukraine «On the State Budget of Ukraine for 2017» dated 15.09.2016, No. 5000]. Access mode: http://w1.c1.rada.gov.ua/ pls/zweb2/webproc4_1?pf3511=60032 (in Ukrainian).

6. Rozporyadzhennya Kabinetu Ministriv Ukrayiny «Deyaki pytannya zapobihannya koruptsiyi v ministerstvakh, inshykh tsentral'nykh orhanakh vykonavchoyi vlady» vid 05.10.2016 r. № 803-r [Order of the Cabinet of Ministers of Ukraine «Some issues of prevention of corruption in ministries, other central executive bodies» dated 05.10.2016, № 803-p]. Access mode: http://zakon5.rada.gov.ua/laws/show/803-2016-\%D1\%80 (in Ukrainian).

7. Ukaz Prezydenta Ukrayiny «Pro Stratehiyu staloho rozvytku «Ukrayina-2020»» № 5/2015 vid 12.01.2015 r. [Decree of the President of Ukraine «On the Strategy of Sustainable Development» Ukraine-2020 «» No.5 / 2015 dated January 12 , 2015]. Access mode: http://zakon3.rada.gov.ua/laws/show/5/2015/ (in Ukrainian).

8. Ukrayina ofitsiyno pryyednalasya do Uhody SOT pro derzhavni zakupivli (GPA) [Ukraine officially acceded to the WTO Government Procurement Agreement (GPA)]. Ministerstvo ekonomichnoho rozvytku i torhivli Ukrayiny. Access mode: http://www.me.gov.ua/News/Detail?lang=uk-UA\&id=5ce283a6-3c61-4fa6-9aed-17d65194daad\&title=UkrainaOf itsiinoPridnalasiaDoUgodiSotProDerzhavniZakupivli-gpa- (in Ukrainian).

9. Ukraine: Request for Extended Arrangement Under the Extended Fund Facility and Cancellation of Stand-By Arrangement-Staff Report; Press Release; and Statement by the Executive Director for Ukraine. International Monetary Fund. - March 12, 2015. - Country Report No. 15/69. Access mode: http:/www.imf.org/external/pubs/cat/longres. aspx?sk=42778.0

10. Ukraine: Second Review Under the Extended Fund Facility and Requests for Waivers of Non-Observance of Performance Criteria, Rephasing of Access and Financing Assurances Review-Press Release; Staff Report; and Statement by the Executive Director for Ukraine. International Monetary Fund. - October 03, 2016. Country Report No. 16/319. Access mode: http://www.imf.org/external/pubs/cat/longres.aspx?sk=44318.0 
Бритова Ганна Валентинівна - кандидат наук з державного управління, докторант

Класичний приватний університет

Адреса: 69002, Запоріжжя, вул. Жуковського 70-Б

E-mail:anna.britova17@gmail.com

Скрильник Свгеній В’ячеславович - магістр

Класичний приватний університет

Адреса: 69002, Запоріжжя, вул. Жуковського 70-Б

Brytova Hanna $V .-P h D$ in public administration, doctoral candidate Classic Private University

Address: 70-B, Zhukovskogo Str., Zaporizhzhia, 69002, Ukraine

E-mail: anna.britova17@gmail.com

Skrylnyk Yevheniy V. - magister

Classic Private University

Address: 70-B, Zhukovskogo Str., Zaporizhzhia, 69002, Ukraine 